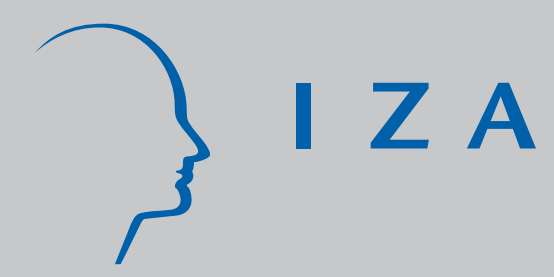

IZA DP No. 242

J ob Creation, J ob Destruction and Employment Growth in Transition Countries in the 90's

Giulia Faggio

J osef Konings

J anuary 2001 


\title{
Job Creation, Job Destruction and Employment Growth in Transition Countries in the 90's
}

\author{
Giulia Faggio \\ LICOS, Centre for Transition Economics and Economics Department, \\ K.U. Leuven, Belgium \\ Jozef Konings \\ LICOS, Centre for Transition Economics and Economics Department, \\ K.U. Leuven, Belgium, CEPR, London and IZA, Bonn
}

Discussion Paper No. 242

January 2001

\author{
IZA \\ P.O. Box 7240 \\ D-53072 Bonn \\ Germany \\ Tel.: +49-228-3894-0 \\ Fax: +49-228-3894-210 \\ Email: iza@iza.org
}

This Discussion Paper is issued within the framework of IZA's research area Labor Markets in Transition. Any opinions expressed here are those of the author(s) and not those of the institute. Research disseminated by IZA may include views on policy, but the institute itself takes no institutional policy positions.

The Institute for the Study of Labor (IZA) in Bonn is a local and virtual international research center and a place of communication between science, politics and business. IZA is an independent, nonprofit limited liability company (Gesellschaft mit beschränkter Haftung) supported by the Deutsche Post AG. The center is associated with the University of Bonn and offers a stimulating research environment through its research networks, research support, and visitors and doctoral programs. IZA engages in (i) original and internationally competitive research in all fields of labor economics, (ii) development of policy concepts, and (iii) dissemination of research results and concepts to the interested public. The current research program deals with (1) mobility and flexibility of labor markets, (2) internationalization of labor markets and European integration, (3) the welfare state and labor markets, (4) labor markets in transition, (5) the future of work, (6) project evaluation and (7) general labor economics.

IZA Discussion Papers often represent preliminary work and are circulated to encourage discussion. Citation of such a paper should account for its provisional character. 
IZA Discussion Paper No. 242

January 2001

\section{ABSTRACT \\ Job Creation, Job Destruction and Employment Growth in Transition Countries in the 90's"}

In this paper we document and analyse gross job flows in five transition countries, Poland, Estonia, Slovenia, Bulgaria and Romania. Using comparable firm level data over the years 19931997, we find that in early transition job destruction dominates job creation, while the latter is picking up as the country enters into a mature stage of transition. Gross job reallocation rates in the more advanced transition countries are comparable to those of Western economies.

We show that the restructuring process is a very heterogeneous one in terms of job creation and destruction: Even in transition countries, hit by very large negative aggregate shocks, we find simultaneous creation and destruction of jobs within narrowly defined sectors, regions and firm types. In addition, we find that most of the job reallocation occurs within sectors and regions, rather than across sectors and regions. We suggest that a measure for restructuring is the excess job reallocation rate and show that the excess job reallocation rate is positively correlated with the net employment growth rate at the sector and regional level.

Finally, we find that ownership and firm size are the most relevant characteristics for understanding different cross-sectional patterns of job reallocation. Foreign firms have higher job creation and higher excess job reallocation rates, while small businesses are the most dynamic in terms of job reallocation. We investigate the job reallocation process at the firm level and test for trade orientation, ownership and size effects. The results show that firm growth depends on ownership and initial size. Trade orientation effects are important for countries in early transition but not for countries in a more mature stage of the transition process.

JEL Classification: J6, P2

Keywords: Job creation, job destruction, transition economies

Jozef Konings

LICOS, K.U.Leuven

Debériotstraat 34

3000 Leuven

Belgium

Tel.: +3216326598

Fax : +32 16326599

Email: jozef.konings@econ.kuleuven.ac.be

\footnotetext{
* This paper has benefited from presentations at the K.U. Leuven, the European Commission (DG II), a World Bank Conference on "Labour Market Adjustment and Restructuring in Transition Economies", Romania, April 1999, the EALE conference 2000. We also thank Hartmut Lehmann, Hylke Vandenbussche, Kathy Terrell, Paul Walsh, Frederic Warzynski and Ciara Whelan, for comments and suggestions. All remaining errors are ours. This paper is part of a Phare Ace grant number p6203-r and of an FWO project on firm restructuring
} 


\section{Introduction}

It is generally known that 'flexibility' of the labour market is an important feature of well-functioning market economies. Davis and Haltiwanger $(1990,1992)$ and Baldwin et al. (1998) report that in the U.S. and in Canada roughly one in every ten jobs is created and one in every ten jobs is destroyed each year. Flexibility of the labour market is important because it permits the rapid reallocation of resources to the most efficient uses and thus it may be vital for economic growth. As suggested by Aghion and Howitt (1994), we might expect a relationship between gross job creation, destruction and productivity growth. Firms (sectors) that engage in restructuring destroy low productivity jobs and create high productivity ones. This leads to high job turnover and an increase in labour productivity. Therefore, a positive correlation between productivity growth and job turnover might be expected. However, a high degree of job reallocation may also have negative effects, at least in the short run, in terms of worker displacement and earnings losses, but the aggregate and long run benefits are more likely to compensate the individual costs.

These issues are particularly relevant for the emerging economies of Central and Eastern Europe. These countries are undertaking reforms in order to move from a central planning system to a market-based economy. Reallocation of economic activities, opening up of the input and product markets, reforms of the labour market and restructuring of existing firms are some of the challenges they face.

The purpose of this paper is to study gross flows of jobs, thereby documenting the role of labour market adjustment in the transition process. In doing so, we might indirectly contribute to the ongoing debate between gradual versus rapid approaches to reform (e.g. Roland, 1994). Haltiwanger and Vodopivec (1998) analyse the role of labour market flexibility for a small transition economy, Estonia. According to their findings, Estonia's transition process is a success story. The country's rapid approach to reform has led the economy to sustainable GDP growth and to rates of job reallocation similar to those reported for western economies. Konings, Lehmann and Schaffer (1996) analyse gross flows of jobs in Poland at the start of transition and find high rates of gross job destruction, which are concentrated in state owned enterprises. This suggests that state owned enterprises in Poland rapidly engaged in initial restructuring or downsizing. Basu, Estrin and Svejnar (1997) and Estrin and Svejnar (1998) find in the context of a labour demand model for the Czech, Slovak Republic 
and Poland that firms adjusted their labour force fairly rapidly at the start of transition. Likewise Sorm and Terell (1999) use the Czech labour force survey to document the flexibility of the labour market in terms of worker flows, which increasingly occur from job-to-job, rather than through unemployment. This is also what may be expected in the more advanced transition countries.

To date, however, there exists no comparative study that uses representative micro data to analyse labour market adjustment in terms of gross flows of jobs during the transition to a market economy in the 1990's and for countries at different stages of transition ${ }^{1}$. This paper makes a first step in filling this gap. To this end, we analyse five transition economies, two of which are fairly large, Poland and Romania, having a total population of 38 and 23 million people, respectively. The other three countries in our analysis, Estonia, Slovenia and Bulgaria, are small open economies. Poland, Estonia and Slovenia are advanced countries in transition. Since the early 1990s, Poland and Estonia aggressively pursued transition by opening the markets, decentralising wage setting and applying labour market reforms. Slovenia has chosen a more gradual but equally successful approach to price liberalisation and privatisation of state-owned enterprises (EBRD, 1998). Bulgaria and Romania have not succeeded in the transformation yet. In the early 1990s, there was a lack of clear commitment by their governments to reform. In more recent years, programs of reforms have been implemented, although hampered by delays and political constraints (EBRD, 1997 and 1998).

The macroeconomic picture shown in Figures 1 and 2 confirms the relatively better performance of Poland, Estonia and Slovenia over Bulgaria and Romania. Ten years after the beginning of transition, Poland, Estonia and Slovenia seem to be consistently on the upward sloping part of the U-shaped curve of aggregate output, while Bulgaria and Romania suffered a severe setback a few years after they experienced a weak recovery. Figure 2 shows that the collapse in employment follows the collapse in output with some lag, but it persists longer.

\footnotetext{
${ }^{1}$ Bilsen and Konings (1998) use a small sample of firms collected through business surveys to study gross job tunover in Bulgaria, Romania and Hungary. The focus of their paper lies on document the relative dynamism of the de novo firms in transition. Here we focus on the traditional sector, which still constitutes the bulk of employment in these economies.
} 
We use an exceptionally rich firm level panel data set for the five countries over the years, 1993-19972, which allows us to construct measures of gross and net job flows. In addition, we are able to investigate the characteristics of the businesses contributing to the job flows, i.e. industry, region, ownership and employer size characteristics. The data also allows us to compare to gross flows of jobs for transition countries with gross flows of jobs for Western countries, computed from the same data source. Given the recent interest in labour economics and other fields in gross job reallocation, we hope that such a comparison will help our understanding of the adjustment process in the labour market. In particular, since transition causes a large macro economic shock it will be interesting to document whether in young market economies firms behaviour is as heterogeneous as in the West and how long it takes before a steady state in the labour market may be reached, i.e. one in which gross job creation equals job destruction.

We investigate also the job reallocation process at the firm level. Since gross job creation and gross job destruction rates are related to firm level employment growth we will also analyse firm level employment growth as in Blanchflower and Burgess (1995). In particular we will investigate firm level employment growth in relation to firm size, taking into account transition-specific effects, i.e. the effects of variables influencing firm growth specific to countries in transition. Thus, we test for the importance of initial size, ownership and trade orientation on firm growth.

The paper proceeds as follows. In section II, we describe the data and we report gross and net job flows at the aggregate level. In section III, we investigate the characteristics of the businesses contributing to the job flows. We report the average magnitude of job flows according to sectors, regions, employer size classes and ownership types. In section IV, we analyse the decomposition of the excess job reallocation rate, while in section $\mathrm{V}$ we look at the relationship between firm growth and firm size. We conclude in section VI.

\footnotetext{
${ }^{2}$ For Romania we only have observations from 1994 onwards.
} 


\section{Data Description and Aggregate Job Flows}

The unbalanced panel data set at our disposal contains information on more than 834 firms in Poland, 233 firms in Estonia, 511 firms in Slovenia and 1548 firms in Bulgaria over the period 1993-1997, and on more than 3776 firms in Romania between 1994-1997. The data consists of the company accounts ${ }^{3}$ of all incorporated firms satisfying at least one of the following criteria: number of employees greater than 100, total assets and operating revenues exceed 16 million and 8 million USD, respectively. Employment data are retrieved from annual company accounts published by the Polish InfoCredit, by the Estonian Krediidiinfo AS, by the Intercredit Ljubljana, by the Creditreform Bulgaria OOD and by the Romanian Chamber of Commerce and Industry.

Our data have several advantages. First, the data are representative for the medium and large firms in the manufacturing and the non-manufacturing sector. Thus we cover most of the traditional firms, while we miss out on the small de novo private firms. Previous work in this field (e.g. Bilsen and Konings, 1998) focused rather on the employment dynamics in de novo private firms relative to traditional firms (state owned and privatised firms), but had to rely on small samples of firm level survey data. The data set that we use, is a large sample of more than 7000 firms covering 5 countries in CEE which provides objective employment information of the firm and which is representative for the traditional firms. A second advantage of the data is that information is provided on narrowly defined sectors (both manufacturing and nonmanufacturing), regions and ownership shares. This information allows us to analyse the reallocation process at the sector, regional level, and by ownership type.

Third, the data are in panel form and cover an intermediate/mature stage of the transition process for the five economies.

Summary statistics on employment in 1993 and 1997 are presented in Table 1. We distinguish among three ownership types in Poland, Bulgaria and Romania: foreign, state and domestic private firms. In the two other countries no ownership information was provided. Furthermore, we do not have exact ownership information

\footnotetext{
${ }^{3}$ Data are available on the Amadeus CD-ROM (Dec. 1998), a Pan European financial database, provided by Bureau van Dijk Electronic Publishing SA.
} 
for all firms in the samples. However, it is most likely that the firms for which we cannot identify the ownership structure are domestic privatised firms for which there exists very dispersed shareholder ownership. Foreign firms are defined as firms with a foreign participation in their stock greater than $50 \%$, and similarly state firms are firms with a state participation greater than 50\%. Domestic private firms are the residual category, which includes privatized firms. We can note that compared to 1993 average employment in all countries has declined, which suggests that firms were reducing over-manning levels. We measure job creation (pos) as the sum of all employment gains in expanding firms in a given year divided by the total employment at the beginning of the year ${ }^{4}$. Likewise we define job destruction (neg) as the sum of all employment losses in contracting firms in a given year divided by total employment at the beginning of the year. The sum of these two gives a measure for gross job reallocation (gross) and the difference yields the net employment growth rate (net). Thus a net growth rate of $-10 \%$ could be generated by a gross job destruction rate of $10 \%$ and a gross job creation rate of $0 \%$, or, a gross job destruction rate of $20 \%$ and a gross job creation rate of $10 \%$.

The latter suggests, however, a much more turbulent and flexible adjustment process in which there are simultaneous contracting and expanding firms and it suggests much more heterogeneous firm behaviour. This might be an important indicator to assess the flexibility of the labour market in transition countries. If labour markets are inflexible then reforms might be hampered exactly due to the poor reallocation between firms, sectors and regions of jobs.

Table 2 shows the various gross job flow measures for the 5 transition countries in this study. The different stages in the transition process become apparent by comparing the countries. In Bulgaria and Romania, the least advanced countries, the job destruction rate always dominates the job creation rate. For example, in 1997, the job destruction rate in Romania is $10 \%$, which means that 1 in every 10 jobs is destroyed, while only 0.4 in every 10 jobs is created per year. The aggregate employment growth rate in Romania in 1997 is $-6.2 \%$, however, the gross job creation rate suggests that despite the fact that the Romanian economy is in decline,

\footnotetext{
${ }^{4}$ Given the nature of our dataset, we cannot interpret firm entry or exit in our sample as firm entry or exit from the market place. Thus, we apply the standard definition of job flow rates and not the one suggested by Davis and Haltiwanger $(1990,1992)$, which divides employment change by the average of employment in periods $\mathrm{t}$ and $\mathrm{t}-1$ and it is appropriate in treating symmetrically entry and exit.
} 
there is some job creation going on, at a rate of $3.7 \%$. This suggests that a reallocation process has started, which cannot be said from Bulgaria with a job creation rate of only $1.4 \%$ and a job destruction rate of $5.2 \%$ by 1997 . The more advanced countries, Poland, Estonia and Slovenia, seem to have moved to a "steady state" situation by 1997 in which job creation equals job destruction, while job destruction was dominating in the earlier years. For all countries we observe that sooner or later job destruction was dominating job creation. This indicates that downsizing has occurred which is consistent with the evolution of aggregate employment shown in figure 2 and which reflects the fact that firms under central planning were generally too large and over-manned. The removal of subsidies presumably has triggered the downsizing and hence the reduction in over-manning levels at the firm. However, this does not necessarily mean that there is no job creation going on or in other words that there are no firms expanding in the economy. It is clear from table 2 that despite the negative aggregate shock that has affected most countries job creation is positive and substantial.

One measure of labour market flexibility is the gross job reallocation rate. It can be noted that the gross job reallocation rate for Poland, Bulgaria and Slovenia fluctuates around 9\%, for Estonia it is somewhat higher, on average $16 \%$ and for Romania its average is around $12 \%$. This measure of gross job reallocation, however, reflects to a large degree the evolution is net aggregate employment and does not necessarily measure the extent that real 'churning' of jobs is taking place.

An alternative measure that we use is therefore the excess job reallocation rate (excess) and is defined as the gross job reallocation rate minus the absolute value of the net employment growth rate (Davis and Haltiwanger, 1992). This measure indicates the amount of job reallocation that results after taking into account the gross job reallocation needed to accommodate a given net employment growth. As the gross job creation rate and the gross job destruction rate measure the flexibility of the labour market, gross job reallocation and, in particular, excess job reallocation can be interpreted also as an index of restructuring. Restructuring of existing firms in transition countries is vital. It has been noticed (Blanchard, 1997) that if firms want to survive, they must undertake fundamental changes in the production as well as in the ownership structure. Firms have to redefine product lines, close down inefficient plants, fire unproductive workers and hire workers and managers with the skills required in a market environment. If reallocation of resources from declining to 
growing firms, from declining to growing sectors or regions takes place smoothly we might expect that restructuring and excess job reallocation are positively correlated. If the reallocation of resources is difficult and the labour market is inflexible we might expect that restructuring is more difficult. We therefore suggest that the turbulence and, thus, the underlying restructuring process will be best reflected in high excess job reallocation rates. We will illustrate this point more in detail when we discuss gross job flows at the sector and regional level in next section.

We can notice that Estonia and Slovenia have on average the highest excess job reallocation, $13 \%$ and $8 \%$ on average respectively. Interestingly, also Romania has a high excess job reallocation rate of $8 \%$ on average, yet Romania is the country that seems to be lagging behind on the basis of the aggregate evolution in employment. The excess job reallocation rate, however, suggests that restructuring is taking place in Romania and in that respect it is doing better than say Bulgaria with an average excess job reallocation rate of $5 \%$.

Based on the reported job flow measures it seems that Estonia stands out as being characterised by a lot of turbulence. This is also found by Haltiwanger and Vodopovic (1998), who report worker flows for Estonia that are similar to those reported by the most dynamic Western economies.

How do the results for transition countries reported in Table 2 compare to gross job flows of mature market economies? At the bottom of Table 2, we present some international comparisons. Annual average job flow rates for four Western European economies are computed using comparable data ${ }^{5}$. In addition, following Bertola (1990), Wells and Grubb (1993) we ranked the countries according to the tightness of the country's employment protection legislation (EPL), which could be considered as a proxy for labour market flexibility. Differences in policy towards EPL and the generosity of the welfare state might be important factors explaining differences in worker and job flows between countries as suggested by Garibaldi (1998), Burgess (1999) and Mortensen and Pissarides (1999). In particular, when employment protection legislation is tough, firing costs are increased which leads to lower job destruction rates and hence lower job creation rates in equilibrium. Hence, countries characterised by tough EPL should also be characterised by lower gross job

\footnotetext{
${ }^{5}$ All figures reported in Table 2 are computed using the information available in Amadeus CD-ROM (Dic.1998).
} 
reallocation. This suggested pattern is confirmed by the figures on excess job reallocation. We could consider Belgium, the Netherlands and Germany as belonging to a group of countries where EPL is relative important and where labour market flexibility is lower than in the UK (or the US). This is also confirmed by the figures on excess job reallocation.

The job flow rates suggest that regulated labour markets in Western Europe have a similar excess job reallocation rate as those for Poland and Slovenia. The Polish labour market is regulated and characterised by the presence of trade unions and an active role of employees and trade unions in the wage bargaining process at the firm level. Also Slovenia has a regulated labour market, characterised by centralised wage setting for the public sector and "social management" of enterprises. In contrast, the results for Estonia are more comparable to those of the UK. In fact, by 1997 the excess job reallocation rate in Estonia is almost 20\% which is more comparable to job reallocation in the US, also a flexible labour market. Bulgaria and Romania are countries in the early phase of transition, still struggling for adopting reforms and deregulating the labour market. They are out of equilibrium with job destruction dominating job creation. 


\section{Job flows by Employer Characteristics}

In this section we analyse gross and net job flows by employer characteristics. We examine differences in job flows by industry, region, employer size and ownership type.

In Table $3 \mathrm{a}$ we document gross job flows according to sector type. Some sectors have higher/less adjustment cost than others, employ different technologies and face more/less degrees of competition. Thus, one can expect that job flows also vary according to sectors.

Even in economies that undergo common negative and large aggregate shocks, we find quite heterogeneous behaviour in terms of job creation and destruction across sectors and countries. While some sectors have a positive net employment growth, most have a negative, but the underlying gross job creation and destruction rates and hence the excess job reallocation rates vary substantially. Thus, even within narrowly defined sectors there exists simultaneous creation and destruction of jobs. The different degrees of job reallocation across sectors show that sectors are not only heterogeneous, but also firms within sectors are heterogeneous. We suggested in the previous section that the excess job reallocation rate might be a good indicator of the degree of restructuring that is going on in a transition economy. If restructuring is positive for growth, we should expect a positive correlation between employment growth at the sector level and the excess job reallocation rate. In Table $3 b$ we report the correlation coefficients between excess job reallocation at the sector level and employment growth at the sector level, pooled over all the years for which we have observations for each country. For all countries we find a positive correlation coefficient, which is consistent with the idea that excess job reallocation is a measure of restructuring that is going on. Interestingly, the correlation coefficient is smaller for Bulgaria and Romania, which suggests that restructuring still has to start there.

In transition, the regional clustering of industries, pursued under central planning, is dismantled. With the implementation of reforms, market forces will change the economic structure artificially imposed on regions under central planning. Thus, one can expect that in transition not only some sectors, but also some regions are hit more than others. Annual average job flows according to regional units are presented in Tables 4-8 for each of the five transition countries, respectively. All 
countries, except for Bulgaria, report high excess job reallocation rates in the capital districts, which are densely populated and have the necessary infrastructure for attracting investment and for supporting economic activity. Just as there are differences in job flows across sectors, each country shows differences in job flows across regions. Some regions have a positive net employment growth, while others have a negative. Thus, some regions are expanding, while others are contracting.

While Poland and Slovenia have a larger number of expanding regions, i.e. regions with a positive net employment growth rate, Estonia has on average more dynamic regions, i.e. regions characterised by simultaneously high job creation and job destruction rates, and thus by high excess job reallocation rates. Bulgaria and Romania are characterised by higher job destruction rates than job creation rates, even if some regions in Romania, such as 'Timis', 'Botosani' and 'Bihor', appear comparable to those in the most advanced countries, showing very high job creation, job destruction and excess job reallocation rates. In addition, job flow regional dispersion is much more pronounced in Romania than in Bulgaria.

In Table 9 we also report the correlation coefficients between excess job reallocation and net employment growth at the regional level. Again we find for all countries a positive correlation between excess job reallocation and net employment growth, which suggests that higher flexibility or turbulence leads to higher growth. Alternatively, it suggests that regions which have restructured more have higher growth. This finding and the findings of Table $3 \mathrm{~b}$ are consistent with the theoretical predictions of Aghion and Howitt (1994) suggesting a positive correlation between job reallocation and growth. This is the result of a process of Schumpeterian competition in which unproductive production units (jobs) are replace with more productive ones, leading to higher growth.

We next look at gross job flows according to enterprise ownership types in Table 10. There is a common pattern that holds across countries. Foreign firms in Poland, Bulgaria and Romania have higher job creation and excess job reallocation rates than state firms, while job destruction rates are lower. Except in Bulgaria, foreign firms are net expanders. Unfortunately, we do not have ownership information on Estonian and Slovenian firms. Nevertheless, from other sources (EBRD, 1998), we know that Estonia has been characterised by high levels of inward foreign direct investment (FDI) since the first privatisation program in 1991-1992. In Slovenia, FDI has been discouraged by excluding foreigners from the privatisation process and by 
the gradual introduction of capital account restrictions since $1995^{6}$. Buch (1999) reports the ratio between FDI and gross capital flows for a number of Central Eastern European countries over the years 1995-1997. As expected, the ratio is higher in Estonia (32.5\%) than in Slovenia (18.9\%). However, the Slovenian ratio is very similar to those reported by other countries, e.g. 19\% in Czech Republic over the same period.

The speed of transition at the individual employer level appears to be linked to ownership. Foreign owned enterprises are the most dynamic ones in terms of job creation. Being free from political and social constraints, they are able to fire unproductive workers and hire new ones, destroy inefficient jobs and create efficient ones, close down plants and establish new ones. Thus, they are able to undertake the fundamental changes necessary for restructuring. Foreign firms bring about new physical and human capital and can implement reforms at the firm level more easily and hence generate positive spillovers. The corporate governance structure is such that the majority of the shares is held by outside foreign owners which makes restructuring easier.

When we look at the gross job creation and destruction rates of private domestic firms we can note that the former is always larger than the one in state firms, while the latter is very comparable. This suggests that privatization leads to better performance in terms of gross job creation, although this is not immediately clear from just looking at the net employment growth rate. The excess job reallocation rate is also always higher than the one in state firms, which suggests that privatized firms engage more in restructuring that state owned ones do. This is what one would expect since state owned firms anticipate privatization in the future which could lead to less incentives to engage in restructuring as suggested by Aghion, Blanchard and Burgess (1995).

A final way to slice the data consists in analysing job flows by employer size class in Table 11. It should be noticed that our sample understates the presence of micro-businesses in these economies. Small firms in our sample refer to the class 0249 employees, where the majority of firms are concentrated in the sub-class 100-249.

\footnotetext{
${ }^{6}$ Capital account restrictions on foreign loans and deposits are in the form of reserve requirements and they have been reduced from 40\%-10\% to 0\% (de facto eliminated) in February 1999.
} 
For all countries, small businesses are the most dynamic in terms of excess job reallocation. They have higher gross job creation rates, but also higher job destruction rates. This feature is a statistical regularity found for all western economies and is often explained by the selection and learning effects associated with young and small enterprises (Jovanovic, 1982). By 1997, after a period of considerable "cleansing" of larger enterprises, some of the patterns observed for western market-based economies appear to be emerging in transition economies, although less pronounced. 


\section{Decomposition of the excess job reallocation}

Having presented the basic patterns of job flows by employer characteristics, i.e. sectors, regions, ownership types and employer sizes, a useful way to summarise the results is to consider the role of employment shifts between and within sectors, regions, ownership types and employer sizes. This is important because it can reveal the micro economic nature of transition. In particular, it is often believed that transition takes the form of reallocation of resources from declining sectors to growing ones and from declining regions to growing ones, which would imply that the sectoral and the regional composition of the economy would drastically change as transition proceeds. However, we will show that this is not the case for the transition countries that we study here. In fact, most of the reallocation of jobs occurs within, rather than across sectors and regions.

Following Davis and Haltiwanger (1990), we decompose the excess job reallocation rate into the between and within components. Considering for instance sectors, the between contribution is measured by summing across sectors the deviation of the absolute net employment change for every sector from the absolute net employment change of the overall economy. The within contribution is measured as the sum across sectors of the excess job reallocation in each sector. Equation (1) reports the formula of this decomposition:

$$
\operatorname{gross}_{t} * N_{t-1}-\left|n e t_{t} * N_{t-1}\right|=(\underbrace{\left.\sum_{s \in S}\left|n e t_{s, t} * N_{t-1}\right|-\left|n e t_{t} * N_{t-1}\right|\right)}_{\begin{array}{c}
\text { Between component of } \\
\text { Excess job reallocation }
\end{array}}+\underbrace{\sum_{s \in S} \operatorname{excess}_{s, t} * N_{t-1},(1)}_{\text {Within component of }}
$$

where $t$ and $t-1$ refer to period $t$ and period $t-1$, while $s$ refers to sector $s$ of the whole set $S$. The same formula applies to regions, ownership types and employer sizes.

In Tables 12-15 we report the between component of this decomposition. Overall, employment shifts within the same 1-digit sector (Table12), region (Table 13), employer size (Table14) and enterprise type (Table15), account for the vast majority of job reallocation.

Table 12 shows the fraction of excess job reallocation that is due to the between sectors component. Only in Estonia, almost $30 \%$ of the excess job 
reallocation can be accounted for by between sectoral shifts in 1997. All the other countries have lower fractions. Thus the job reallocation rates in transition countries should be considered primarily as reflecting employment shifts among firms in the same one-digit industries. Compared to the US and Canada the shifts of jobs between sectors in transition countries are still substantial. Baldwin et al. (1998) report that between-sector shifts only account for $2.5 \%$ of excess job reallocation in Canada and $3.6 \%$ of excess job reallocation in the US.

For Poland, Bulgaria and Romania, we are able to compute the fraction of excess job reallocation resulting from employment shifts between 2-digit industries, the results were very similar.

Tables 13,14 and 15 show the same decomposition for regions, size classes of firms and enterprise ownership types. The same result emerges at the one discussed above. The between region/size class/ownership type shifts account for a minor fraction of excess job reallocation in transition countries. In Estonia, however, we always find that a larger fraction of job reallocation can be explained by 'between shifts'. This may be due to the fact that Estonia is a very small open economy with a limited number of firms in each region or sector. 


\section{Job reallocation at the firm level}

The reported gross job flows in the previous sections are the result of simultaneous contraction and expansion of firms in a sector or region. In this section we identify the factors that determine firm level job creation and destruction, i.e. firm level expansion and contraction. To understand job reallocation at the aggregate or sectoral level it is therefore important to understand firm level employment growth. In the growth-of-firms literature (e.g. Sutton, 1997) the main area of interest is the relationship between the mean growth rate and firm size. This relationship is important for the equilibrium size distribution of firms which may be relevant for the degree of competition in markets. We analyse the relationship between firm employment growth and firm size, but enlarge our specification in order to take into account transition-specific effects, i.e. trade orientation and ownership effects. Many empirical studies for western economies (e.g. Blanchflower and Burgess, 1995 and references therein) find a negative relationship between firm size and growth, leading to a rejection of Gibrat's law stating the firm growth is independent of firm size. In the context of transition, the failure of the Gibrat's Law might be interpreted as a test of initial restructuring of large enterprises: under central planning firms were too large and inefficient by the standards of market economies. Transition requires at first the downsizing of large state-owned enterprises. Therefore, looking at the relationship between firm growth and firm size, we might expect to find a negative and significant effect of initial size on firm growth.

In the following analysis, we test also the relevance of trade orientation effects to employment firm growth. According to Repkine and Walsh (1999), in early transition viable firms were those in trade oriented sectors, i.e. sectors exporting towards the EU markets before the collapse of central planning. Repkine and Walsh (1999) notice that in Central and Eastern Europe a substantial number of sectors was trading with Western Europe before the collapse of communism. For such sectors, the production of a viable competitive good was important in order to be able to export to a market economy. In contrast, sectors producing for the Soviet market were guided by the central planner without taking into account demand patterns and viability. With the collapse of central planning, it is therefore possible to observe simultaneously 
viable firms, which are able to sustain production and face increasingly international competition, while other firms produce low quality goods and are subject to downsizing, restructuring or eventually exit.

We follow Repkine and Walsh (1999) and take their indicator of trade orientation, which identifies sectors that were having trade flows to the EU already in $1988^{7}$. We expect that in early transition viable firms, operating in 'traded' sectors, have a better performance than firms operating in 'non-traded' sectors. The reason for this is that firms operating in 'traded' sectors were exposed to competitive markets already during central planning and therefore were forced to produce viable products. Such firms need less restructuring or will restructure in the very early phases of transition as they have incentives given that they are producing a viable product and therefore they have a potential for growth. Firms operating in the 'non-traded' sectors, however, were producing non-viable products, imposed by the central planner. With the collapse of communism the (artificial) demand for their products also collapsed. Restructuring in those type of firms might prove to be much more difficult or not even feasible (Repkine and Walsh, 1999).

We use the following specification to test employment growth (reallocation) at the firm level, which can explain gross job flows at the aggregate level:

$$
\begin{aligned}
& \Delta n_{i, t}=\beta_{0}+\beta_{1} n_{i, t-2}+\beta_{2} \text { trade }+\beta_{3} \text { foreign }+\beta_{4} \text { state }+\beta_{5} n_{i, t-2} * \text { foreign }+ \\
& \beta_{6} n_{i, t-2} * \text { state }+\sum_{j} \beta_{j} * X_{j}+\varepsilon_{i, t},
\end{aligned}
$$

where the dependent variable $\left(\Delta n_{i, t}\right)$ is the annual employment growth rate for firm $i$ at time $t$ and $n_{i, t-2}$ is the log firm size at time $\mathrm{t}-2$. We further include a trade orientation dummy (trade), ownership dummies (foreign and state, the benchmark being domestic private), interaction terms between lagged firm size and ownership dummies, regional and time dummies (variables in $X_{j}$ ). $\varepsilon_{i, t}$ is an error term.

Following Hamilton (1998), we use robust regression analysis to estimate equation (2). Robust estimation achieves almost OLS efficiency in situations in which the error terms are independently but not normally distributed. We believe this to be a

\footnotetext{
${ }^{7}$ A sector is classified as a 'traded' sector if the fraction of sector export flows over the total export flows in the corresponding industry is greater than 5\%. A sector is defined according to the Nace-Clio 3-digit classification, while an industry by the corresponding Nace-Clio 2-digit classification.
} 
sensible approach given that there are a large number of outliers in our sample and that we are dealing with transition data ${ }^{8}$. The results obtained are reported in Tables $16-20$.

We use five nested specifications and start with discussing the effects of ownership on firm level employment growth for the three countries, Poland, Bulgaria and Romania, for which ownership data were available. We find that in all specifications for Poland and Romania there exists a negative effect of state ownership on firm employment growth compared to majority domestic private ownership, while in Bulgaria the negative effect of state ownership drops out once controlling for firm size (see column 4). Since the effect of firm size controls for initial restructuring (the downsizing which was necessary to eliminate labor hoarding), we pick up a pure ownership effect on firm growth or firm performance. The fact that we do not find a negative effect of state firms in Bulgaria suggests that in the country domestic private or privatised firms have very similar performance compared to state firms. This could be an indication that in privatised firms not much restructuring has occurred, perhaps due to a dominant presence of insiders. In column (5) we allow for different initial size effects according to different categories of firms. In this case, the direct effect of state ownership on firm growth is negative also in Bulgaria. However, for larger firms the initial size effect disappears, which can be seen from the positive interaction effect. A positive interaction effect between lagged size and state ownership is found for all the three countries, which suggests that larger state firms do not perform worse than large privatised firms. This also implies that, if firms did not engage in initial downsizing (restructuring), privatised firms and state firms perform in a very similar way. Thus, privatisation only works if firms have engaged sufficiently in initial restructuring. This result confirms earlier work based on firm level survey data in which no significant difference was found between privatised and state owned enterprises in terms of employment adjustment (Konings, 1997; Richter and Schaffer, 1996).

The results for foreign ownership indicate that foreign firms perform - not surprisingly - better than state and privatised firms, at least in Poland and Romania

\footnotetext{
${ }^{8}$ We performed also OLS estimations; the sign of the estimates are similar, but the significance levels are lower.
} 
(column 5). In Bulgaria, however, once we control for different size effects according to ownership, foreign firms do not perform any better.

The results on ownership are consistent with the gross job flows that we reported according to ownership. We also find that on average privatised firms have engaged in initial downsizing, which can be seen from the negative and significant coefficient of lagged size on employment. As noticed, this effect is counter-acted for state firms, such that in state firms there is no initial size effect. This indicates that on average privatised firms have downsized more than state firms, which will lead to a better performance of privatised firms compared to state firms. However, privatised firms that did not downsize have the same employment performance as state firms. Although we do not have information on ownership for Estonia and Slovenia we find a strong negative initial size effect for these countries. Interestingly, the size effect is largest in Estonia (-0.04), followed by Slovenia (-0.014) and Poland (-0.01) and then Romania and Bulgaria (-0.006). Thus, large firms in the more advanced countries downsize faster than large firms in the more backward countries. This might reflect the continued government intervention in large firms in Bulgaria and Romania.

Finally, we find that trade orientation has a positive effect in Romania and Bulgaria on employment growth, but a negative one in Estonia and Slovenia, while in Poland we do not find any statistically significant effect. This suggests that in early transition product viability, measured by trade orientation, matters. As transition progresses, the effect of trade orientation on firm performance becomes negligible or even negative. Firms in trade oriented sectors are exposed to international competition which increases as transition proceeds. The effects of competition on firm performance can be of two types. It might be that a high level of product market competition is detrimental for firm performance ${ }^{9}$. Firms in transition economies are unprepared for aggressive competition and, not supported, are likely to exit. On this basis, a gradual approach to trade and capital flows liberalisation has been suggested and adopted in some countries, such as in Slovenia (EBRD, 1998). It is also possible that a high degree of competition enhances firm restructuring and thus the downsizing of larger firms, as it has been the case in Estonia (EBRD, 1998). Both effects predict a negative relationship between firm growth and the trade orientation dummy in the 
most advanced countries. In our analysis we can not distinguish between these two different effects of competition on firm performance.

\footnotetext{
${ }^{9}$ Several theoretical contributions on the relation between market structure and innovation have suggested a negative effect of tough competition on the rate of inventive activity (see among others the seminal paper by Kamien and Schwartz, 1968, and more recently Aghion and Howitt, 1994).
} 


\section{Summary and Conclusions}

This paper is the first to present a comprehensive and comparable analysis of job flows during the transition process. Using an exceptionally rich data set on firm level data over the years 1993-1997, we analyse the dynamics of job flows in five transition countries, Poland, Estonia, Slovenia, Bulgaria and Romania. We find that in the early stages of transition job destruction dominates job creation. However, as transition progresses, job destruction equals job destruction in the more advanced countries, such as Poland, Estonia and Slovenia, while job destruction remains high in the less advanced countries, such as Bulgaria and Romania.

We find also that gross job reallocation varies across countries and that job flow rates in the more advanced countries are comparable to those found in Western economies. In addition, differences across countries may be linked to differences in labour and product market flexibility due to employment protection legislation (EPL) and openness of the economy.

It seems that a rapid approach to reforms, like in Estonia, has resulted in higher job flows rates than those shown by other countries, like in Slovenia, where a more gradual approach to reforms has been adopted.

We find that firms, even in transition economies which are hit by severe shocks, behave in a very heterogeneous way regarding their employment decisions. We find that even within narrowly defined sectors, regions and firm size classes, there exists simultaneous creation and destruction of jobs. We suggest that a good indicator of restructuring is measured by the excess job reallocation rate and we demonstrate that there is a positive correlation between the excess job reallocation rate and net employment growth at the regional and sectoral level. Moreover, we show that job reallocation occurs predominantly within sectors and regions rather than between sectors and regions, which suggests that we should think of transition not in terms of job flows from declining sectors or regions to growing ones, but rather in terms from declining firms to growing firms within the same sector and region.

Finally, we analyse the job reallocation process at the firm level. We find that job creation is explained by initial downsizing (firm size), ownership and trade orientation effects. The latter could be seen as a proxy for firm viability. In addition, we find that large state firms perform the same as large privatised firms, however, if 
the latter have downsized, they will do better. Foreign firms perform better compared to privatised firms and state ones. Finally, the effect of initial downsizing is largest in the more advanced countries.

The results in this paper suggest that also in transition countries a lot of turbulence occurs, which cannot be seen if one just looks at the macro economic data. It also suggests that the restructuring process is one that is very heterogeneous. 


\section{References}

Aghion, P. and P. Howitt, (1994), "Growth and Unemployment", Review of Economic Studies, Vol.61, pp. 477-494.

Aghion, P., Blanchard O. and Burgess, R. (1995). "The Behaviour of State Firms in Eastern Europe Pre-Privatisation”, European Economic Review, Vol. 38, pp.13271350 .

Baldwin, J., T. Dunne and J. Haltiwanger (1998), "A Comparison of Job Creation and Job Destruction in Canada and the United States", The Review of Economics and Statistics, Vol. LXXX (3), pp.347-356.

Basu, S., Estrin S. and J. Svejnar (1997), "Employment and wage behaviour of industrial enterprises in transition economies: The cases of Poland and Czechoslovakia", Economics of Transition, Vol.5 (2), pp. 271-287.

Bertola, G. (1990), "Job Security, Employment and Wages", European Economic Review, Vol.34, pp.851-879.

Bilsen, V. and Konings, J. (1998). "Job Creation, Job Destruction, and Growth of Newly Established, Privatized and State-Owned Enterprises in Transition Economies: Survey evidence from Bulgaria, Hungary and Romania", Journal of Comparative Economics, Vol. 26 , pp. 429-445.

Blanchard, O. (1997), “The Economics of the Post-communist Transition”, Clarendon Press Oxford.

Blanchflower, D. and Burgess, S. (1995). "Job Creation and Job Destruction in GreatBritain, 1980-1990, Industrial and Labor Relations Review, October, pp. 17-38.

Buch, C.M. (1999), “Taxing Short-Term Capital Flows?”, Kiel Institute for World Economics, mimeo.

Burgess, S. (1999). "Labour Reallocation and Employment Protection", CEP discussion Paper.

Davis, S. and J. Haltiwanger (1990), "Gross Job Creation and Destruction: Microeconomic Evidence and Macroeconomic Implications", NBER Macroeconomic Annual 5, pp.123-168.

Davis, S. and J. Haltiwanger (1992), "Gross Job Creation, Gross Job Destruction and Employment Reallocation", Quarterly Journal of Economics, Vol.107 (3), pp. 819863.

EBRD, Transition Report (1997).

EBRD, Transition Report (1998). 
Estrin, S. and J. Svenjar (1998), "The Effects of Output, Ownership and Legal form on Employment and Wages in Central European Firms" in S. Commander, ed., Enterprise Restructuring and Unemployment in Models of Transition, Washington DC: EDI/World Bank.

Garibaldi, P. (1998). 'Job Flow Dynamics and Firing Restrictions', European Economics Review, Vol. 42, pp. 224-275.

Hamilton, L. (1998), Statistics with Stata 5. Pacific Grove, CA: Duxbury Press, Brooks/Cole Publishing, 1998.

Haltiwanger, J. and M. Vodopivec (1998), "Gross Worker and Job Flows in a Transition Economy: An analysis of Estonia", University of Maryland, mimeo.

Jovanovic, B., (1982), "Selection and the Evolution of Industry", Econometrica, Vol. 50 (3), pp.649-70.

Kamien, M. and N. Schwartz, (1968), "Induced Factor Augmenting Technical Progress from a Microeconomic Viewpoint, Econometrica, Vol.37, pp.668-684.

Konings J., H. Lehmann and M. Schaffer (1996), "Employment Growth, Job Creation and Job Destruction in Polish Industry: 1988-91, Labour Economics, Vol.3, pp.299317.

Konings, J. (1997). "Firm Growth and Ownership", Economic Letters, Vol.55, pp.413-418.

Mortensen, D.T. and C. Pissarides (1999). "Job Creation, Job Destruction and Equilbrium Unemployment”, CEP Discussion Paper, LSE

Repkine, A. and P. Walsh (1999), "European Trade and Foreign Direct Investment UShaping Industrial Output in Central and Eastern Europe: Theory and Evidence", Journal of Comparative Economics, December.

Richter, A. and Schaffer, M, (1996). "Growth, Investment, and Newly-Established Firms in Russian Manufacturing", in Commander, S., Fan, Q. and Schaffer, M. (eds.), Enterprise Restructuring and Economic Policy in Russia, EDI/World Bank

Roland, G. (1994), "On the Speed and Sequencing of Privatisation and Restructuring", Economic Journal, Vol. 104 (426), pp.1158-1169.

Sorm, V. and K. Terrell (1999), "A Comparative Look at Labor Mobility in the Czech Republic: Where Have All the Workers Gone?", The Davidson Institute Working Paper Series, 140/1999.

Sutton, J. (1997), "Gibrat Legacy", Journal of Economic Literature, Vol. XXXV, pp.40-59.

Wells and Grubb (1993). "Employment Regulation and Atypical Work in the EC, mimeo, OECD Paris. 


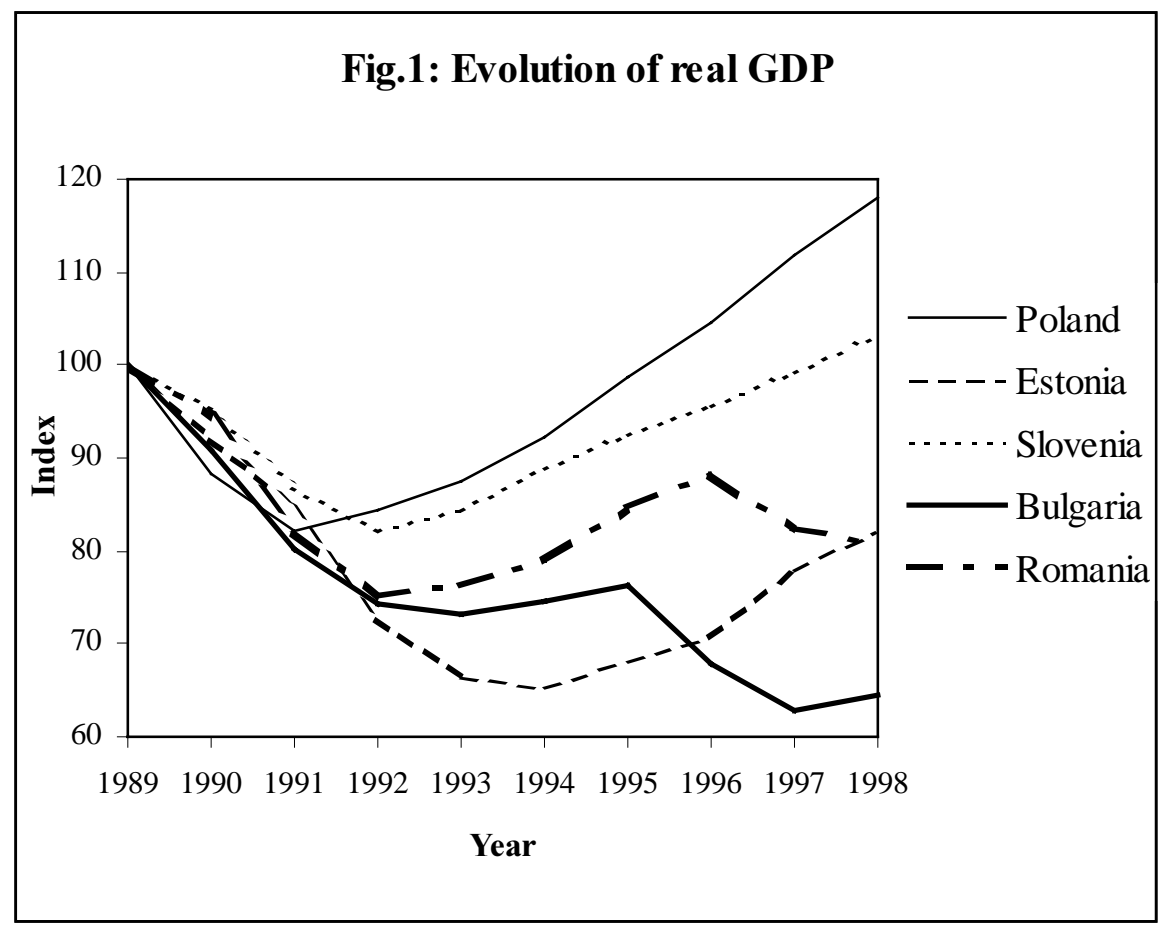

Source: Transition report, EBRD (1998)

Fig.2: Evolution of Aggregate Employment

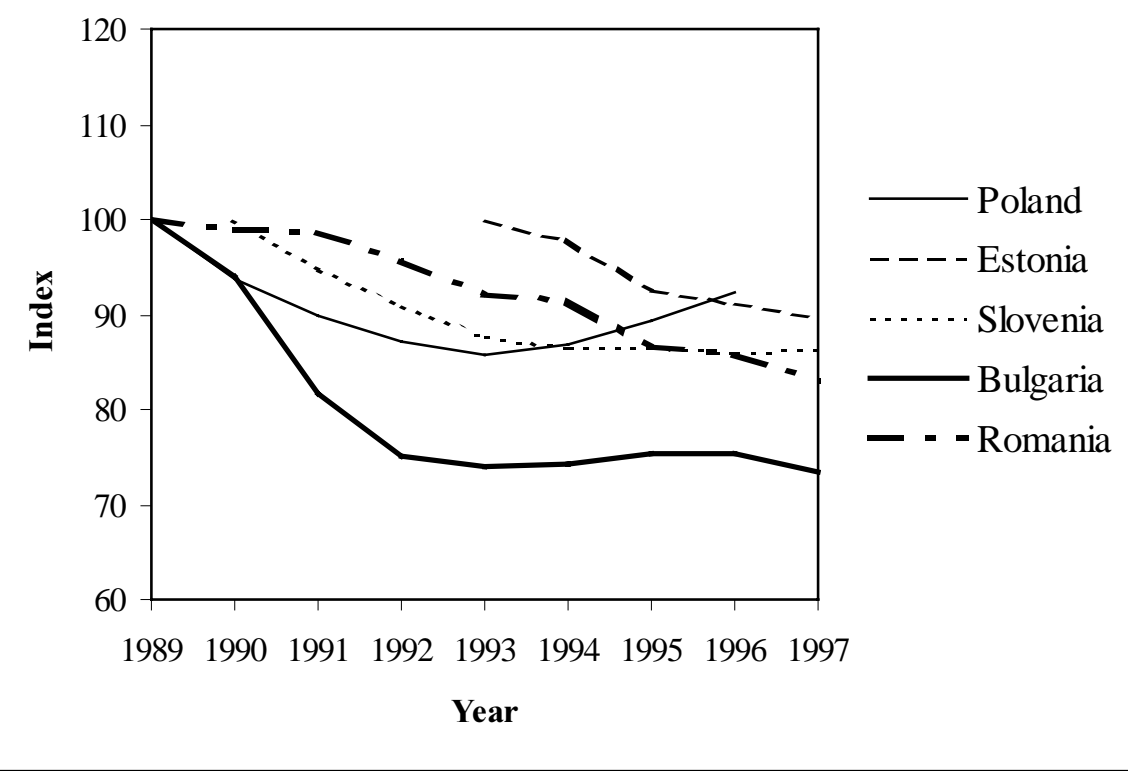

Note: Employment data for Estonia and Slovenia are available only from 1994 and 1991, respectively.

Source: Transition report, EBRD (1998) 
Table 1: Description of the sample according to ownership types $(1993,1997)$

\begin{tabular}{|c|c|c|c|c|c|c|}
\hline \multirow{2}{*}{ Country } & \multicolumn{3}{|c|}{1993} & \multicolumn{3}{|c|}{1997} \\
\hline & $\begin{array}{l}\text { Number of } \\
\text { firms }\end{array}$ & $\begin{array}{c}\text { Average } \\
\text { employment }\end{array}$ & $\begin{array}{l}\text { Standard } \\
\text { Deviation }\end{array}$ & $\begin{array}{l}\text { Number of } \\
\text { firms }\end{array}$ & $\begin{array}{c}\text { Average } \\
\text { employment }\end{array}$ & $\begin{array}{c}\text { Standard } \\
\text { Deviation }\end{array}$ \\
\hline Poland & & & & & & \\
\hline Overall & 834 & 1278 & 2735 & 2130 & 724 & 1995 \\
\hline State firms & 72 & 2448 & 4030 & 78 & 3053 & 8674 \\
\hline Foreign firms & 47 & 1008 & 1032 & 56 & 1071 & 1435 \\
\hline $\begin{array}{l}\text { Domestic private } \\
\text { firms }\end{array}$ & 113 & 1104 & 1608 & 164 & 945 & 1036 \\
\hline Estonia & & & & & & \\
\hline Overall & 233 & 396 & 446 & 528 & 244 & 391 \\
\hline $\begin{array}{l}\text { Slovenia } \\
\text { Overall }\end{array}$ & 511 & 419 & 626 & 520 & 389 & 504 \\
\hline Bulgaria & & & & & & \\
\hline Overall & 1548 & 624 & 2059 & 2458 & 396 & 1549 \\
\hline State firms & 586 & 883 & 3199 & 897 & 524 & 2308 \\
\hline Foreign firms & 38 & 1087 & 1399 & 71 & 751 & 1097 \\
\hline $\begin{array}{l}\text { Domestic private } \\
\text { firms }\end{array}$ & 745 & 433 & 612 & 943 & 352 & 993 \\
\hline Romania* & & & & & & \\
\hline Overall & 3776 & 722 & 1868 & 4558 & 556 & 1869 \\
\hline State firms & 1648 & 860 & 1575 & 1702 & 670 & 1357 \\
\hline Foreign firms & 88 & 370 & 715 & 120 & 469 & 631 \\
\hline $\begin{array}{l}\text { Domestic private } \\
\text { firms }\end{array}$ & 1166 & 527 & 959 & 1323 & 445 & 966 \\
\hline
\end{tabular}

Note: $(*) 1993$ figures refer to 1994 ones. The ownership classification is not available for Estonia and Slovenia. 
Table 2: Annual net and gross job flows for Poland, Estonia, Slovenia, Bulgaria and Romania (1993-1997)

\begin{tabular}{|c|c|c|c|c|c|}
\hline Year/Country & Pos & neg & gross & net & excess \\
\hline \multicolumn{6}{|l|}{ Poland } \\
\hline 1994 & 3.0 & 6.8 & 9.8 & -3.8 & 6.0 \\
\hline 1995 & 3.6 & 6.0 & 9.6 & -2.4 & 7.2 \\
\hline 1996 & 3.0 & 5.0 & 8.0 & -2.0 & 6.0 \\
\hline 1997 & 3.0 & 3.7 & 6.7 & -0.6 & 6.1 \\
\hline \multicolumn{6}{|l|}{ Estonia } \\
\hline 1994 & 4.6 & 9.2 & 13.8 & -4.6 & 9.2 \\
\hline 1995 & 6.4 & 7.3 & 13.8 & -0.9 & 12.9 \\
\hline 1996 & 11.2 & 7.2 & 18.4 & 4.0 & 14.4 \\
\hline 1997 & 9.3 & 8.8 & 18.1 & 0.6 & 17.5 \\
\hline \multicolumn{6}{|l|}{ Slovenia } \\
\hline 1994 & 3.9 & 4.2 & 8.1 & -0.2 & 7.9 \\
\hline 1995 & 4.6 & 5.9 & 10.5 & -1.3 & 9.2 \\
\hline 1996 & 5.5 & 5.3 & 10.8 & 0.2 & 10.5 \\
\hline 1997 & 3.3 & 5.4 & 8.8 & -2.1 & 6.7 \\
\hline \multicolumn{6}{|l|}{ Bulgaria } \\
\hline 1994 & 0.8 & 7.2 & 8.0 & -6.3 & 1.7 \\
\hline 1995 & 3.2 & 3.3 & 6.5 & -0.1 & 6.4 \\
\hline 1996 & 4.1 & 7.0 & 11.1 & -2.9 & 8.2 \\
\hline 1997 & 1.4 & 5.2 & 6.6 & -3.7 & 2.9 \\
\hline \multicolumn{6}{|l|}{ Romania } \\
\hline 1995 & 4.7 & 10.1 & 14.8 & -5.4 & 9.4 \\
\hline 1996 & 3.6 & 7.1 & 10.7 & -3.5 & 7.2 \\
\hline 1997 & 3.7 & 9.9 & 13.6 & -6.2 & 7.4 \\
\hline \multicolumn{6}{|c|}{ International comparisons* } \\
\hline Belgium & 3.7 & 3.4 & 7.1 & 0.3 & 5.7 \\
\hline Netherlands & 6.5 & 2.7 & 9.1 & 3.8 & 5.2 \\
\hline Germany & 4.6 & 4.1 & 8.7 & 0.4 & 6.2 \\
\hline U.K. & 5.4 & 5.4 & 10.8 & -0.1 & 9.0 \\
\hline \multicolumn{6}{|c|}{$\begin{array}{l}\text { Note: pos }=\text { gross job creation rate, neg }=\text { gross destruction rate, gross }=\text { gross reallocation rate } \\
(\text { pos }+ \text { neg), net }=\text { net employment growth rate (pos-neg), excess }=\text { excess job reallocation rate (gross- } \\
\mid \text { net } \mid) .(*) \text { : Figures refer to averages over the years 1989-1995 for Belgium, 1988-1995 for The } \\
\text { Netherlands and Germany, } 1987-1995 \text { for U.K. Using averages, job flows rate definitions do not hold } \\
\text { exactly. Rankings are in order of increasingly loose regulation (Bertola, 1990). }\end{array}$} \\
\hline
\end{tabular}


Table 3a: Annual average job flows according to sector classification (NACE code, rev.1), 1994-1997

\begin{tabular}{|c|c|c|c|c|c|}
\hline Country/Sector & pos & neg & gross & net & Excess \\
\hline \multicolumn{6}{|l|}{ Poland } \\
\hline Agriculture and fishing & 2.0 & 8.8 & 10.8 & -6.7 & 4.0 \\
\hline Mining and quarrying & 1.0 & 4.0 & 5.0 & -3.0 & 2.1 \\
\hline Manufacturing & 3.3 & 5.0 & 8.3 & -1.7 & 6.5 \\
\hline Electricity, gas and water supply & 2.4 & 4.6 & 7.0 & -2.2 & 4.8 \\
\hline Construction & 5.8 & 8.5 & 14.4 & -2.7 & 9.0 \\
\hline Trade & 7.5 & 8.0 & 15.5 & -0.5 & 13.9 \\
\hline Transport and communication & 2.3 & 10.9 & 13.2 & -8.6 & 4.6 \\
\hline Business services & 6.6 & 7.2 & 13.8 & -0.7 & 10.8 \\
\hline Public services & 6.6 & 2.4 & 9.0 & 4.2 & 4.7 \\
\hline \multicolumn{6}{|l|}{ Estonia } \\
\hline Agriculture and fishing & 4.4 & 5.9 & 10.2 & -1.5 & 5.8 \\
\hline Manufacturing & 5.0 & 7.9 & 12.9 & -2.9 & 9.9 \\
\hline Construction & 20.3 & 7.2 & 27.5 & 13.1 & 13.0 \\
\hline Trade & 7.5 & 10.0 & 17.2 & -2.1 & 11.3 \\
\hline Transport and communication & 9.7 & 9.9 & 19.6 & -0.2 & 12.0 \\
\hline Business services & 31.0 & 6.7 & 37.6 & 24.3 & 6.1 \\
\hline Public services & 31.4 & 16.9 & 48.3 & 14.5 & 9.6 \\
\hline \multicolumn{6}{|l|}{ Slovenia } \\
\hline Agriculture and fishing & 1.4 & 6.3 & 7.7 & -5.0 & 2.7 \\
\hline Manufacturing & 3.4 & 4.8 & 8.2 & -1.4 & 6.4 \\
\hline Electricity, gas and water supply & 0.5 & 0.7 & 1.2 & -0.1 & 0.4 \\
\hline Construction & 9.7 & 3.9 & 13.6 & 5.7 & 7.4 \\
\hline Trade & 4.9 & 4.1 & 9.1 & 0.8 & 5.6 \\
\hline Transport and communication & 2.7 & 11.6 & 14.3 & -8.9 & 3.4 \\
\hline Business services & 26.6 & 9.2 & 35.8 & 17.4 & 12.7 \\
\hline Public services & 9.3 & 0.7 & 10.0 & 8.6 & 1.4 \\
\hline \multicolumn{6}{|l|}{ Bulgaria } \\
\hline Agriculture and fishing & 4.4 & 15.0 & 19.4 & -10.6 & 5.0 \\
\hline Mining and quarrying & 1.7 & 3.8 & 5.6 & -2.1 & 1.9 \\
\hline Manufacturing & 2.4 & 5.6 & 8.0 & -3.2 & 4.6 \\
\hline Electricity, gas and water supply & 3.0 & 2.8 & 5.8 & 0.3 & 1.3 \\
\hline Construction & 2.3 & 7.2 & 9.5 & -4.9 & 4.6 \\
\hline Trade & 3.5 & 7.4 & 10.9 & -3.9 & 6.6 \\
\hline Transport and communication & 1.1 & 4.2 & 5.3 & -3.2 & 2.1 \\
\hline Business services & 1.2 & 11.2 & 12.4 & -10.0 & 2.4 \\
\hline Public services & 7.4 & 5.5 & 13.0 & 1.9 & 5.0 \\
\hline \multicolumn{6}{|l|}{ Romania* } \\
\hline Agriculture and fishing & 5.1 & 14.4 & 19.6 & -9.3 & 10.3 \\
\hline Mining and quarrying & 2.7 & 7.2 & 10.0 & -4.5 & 5.4 \\
\hline Manufacturing & 3.0 & 8.1 & 11.2 & -5.1 & 6.1 \\
\hline Electricity, gas and water supply & 1.7 & 3.3 & 5.0 & -1.5 & 2.7 \\
\hline Construction & 4.6 & 12.4 & 17.0 & -7.8 & 9.1 \\
\hline Trade & 7.0 & 9.9 & 16.9 & -2.9 & 11.9 \\
\hline Transport and communication & 2.6 & 6.6 & 9.2 & -4.0 & 5.3 \\
\hline Business services & 3.3 & 9.5 & 12.8 & -6.1 & 6.7 \\
\hline Public services & 14.9 & 7.0 & 22.0 & 7.9 & 14.1 \\
\hline
\end{tabular}

Note: (*) Romanian figures refer to 1995-1997 averages. 
Table 3b: Correlation coefficients

\begin{tabular}{l|l}
\hline Country & $\begin{array}{l}\text { Correlation between excess job reallocation and net employment growth } \\
\text { at the sector level }\end{array}$ \\
\hline Poland & 0.217 \\
Estonia & 0.268 \\
Slovenia & 0.517 \\
Bulgaria & 0.107 \\
Romania & 0.142 \\
\hline
\end{tabular}


Table 4: Annual average job flows in Poland according to regional units, 1994-1997

\begin{tabular}{|c|c|c|c|c|c|}
\hline Voivodship & pos & $\mathrm{Neg}$ & gross & net & excess \\
\hline Warszawskie & 4.7 & 5.4 & 10.1 & -0.6 & 9.0 \\
\hline Bialskopodlaskie & 5.8 & 1.0 & 6.8 & 4.8 & 1.8 \\
\hline Bialostockie & 2.5 & 3.4 & 5.9 & -0.9 & 4.5 \\
\hline Bielskie & 2.9 & 4.5 & 7.4 & -1.6 & 5.7 \\
\hline Bydgoskie & 2.6 & 3.2 & 5.8 & -0.6 & 5.1 \\
\hline Chelmskie & 2.4 & 2.2 & 4.7 & 0.2 & 3.7 \\
\hline Ciechanowskie & 2.0 & 6.2 & 8.2 & -4.2 & 3.1 \\
\hline Czestochowskie & 1.7 & 4.6 & 6.3 & -2.9 & 3.4 \\
\hline Elblaskie & 4.3 & 6.5 & 10.8 & -2.2 & 8.2 \\
\hline Gdanskie & 3.1 & 10.1 & 13.3 & -7.0 & 6.3 \\
\hline Gorzowskie & 5.9 & 3.8 & 9.7 & 2.0 & 4.0 \\
\hline Jeleniogorskie & 2.3 & 2.2 & 4.5 & 0.1 & 2.2 \\
\hline Kaliskie & 3.7 & 3.4 & 7.1 & 0.4 & 4.0 \\
\hline Katowickie & 1.6 & 5.6 & 7.2 & -4.0 & 3.2 \\
\hline Kieleckie & 3.4 & 5.6 & 9.0 & -2.1 & 6.7 \\
\hline Koninskie & 1.1 & 3.3 & 4.4 & -2.2 & 1.6 \\
\hline Koszalinskie & 2.2 & 5.7 & 7.9 & -3.4 & 4.1 \\
\hline Krakowskie & 3.2 & 5.5 & 8.7 & -2.3 & 4.7 \\
\hline Krosnienskie & 4.5 & 5.6 & 10.2 & -1.1 & 3.3 \\
\hline Legnickie & 2.1 & 5.3 & 7.5 & -3.2 & 4.2 \\
\hline Leszczynskie & 4.0 & 1.9 & 5.9 & 2.1 & 3.7 \\
\hline Lubelskie & 5.7 & 5.7 & 11.5 & -0.1 & 5.8 \\
\hline Lomzynskie & 1.8 & 6.5 & 8.3 & -4.7 & 1.9 \\
\hline Lodzkie & 2.2 & 4.8 & 7.0 & -2.6 & 4.3 \\
\hline Nowosadeckie & 2.7 & 9.2 & 11.8 & -6.5 & 5.3 \\
\hline Olsztynskie & 5.1 & 2.8 & 7.9 & 2.2 & 4.3 \\
\hline Opolskie & 3.2 & 5.3 & 8.5 & -2.1 & 5.2 \\
\hline Ostroleckie & 11.5 & 0.7 & 12.2 & 10.7 & 1.5 \\
\hline Pilskie & 13.0 & 6.6 & 19.6 & 6.4 & 2.9 \\
\hline Piotrkowskie & 1.6 & 3.1 & 4.8 & -1.5 & 2.4 \\
\hline Plockie & 2.2 & 3.8 & 6.0 & -1.5 & 4.4 \\
\hline Poznanskie & 3.8 & 7.2 & 10.7 & -3.4 & 6.8 \\
\hline Przemyskie & 5.5 & 3.3 & 8.8 & 2.2 & 4.4 \\
\hline Radomskie & 4.1 & 4.7 & 8.8 & -0.6 & 5.1 \\
\hline Rzeszowskie & 6.2 & 4.1 & 10.4 & 2.1 & 4.4 \\
\hline Siedleckie & 2.5 & 3.6 & 6.1 & -1.0 & 3.4 \\
\hline Sieradzkie & 1.6 & 2.6 & 4.2 & -1.0 & 1.1 \\
\hline Skierniewickie & 2.1 & 9.6 & 11.8 & -7.5 & 4.0 \\
\hline Slupskie & 1.8 & 5.0 & 6.9 & -3.2 & 3.7 \\
\hline Suwalskie & 6.6 & 0.7 & 7.3 & 5.9 & 1.4 \\
\hline Szczecinskie & 4.5 & 4.2 & 8.7 & 0.3 & 6.6 \\
\hline Tarnobrzeskie & 1.5 & 5.2 & 6.8 & -3.7 & 1.9 \\
\hline Tarnowskie & 1.2 & 3.4 & 4.6 & -2.1 & 2.3 \\
\hline Torunskie & 2.9 & 7.6 & 10.5 & -4.6 & 5.9 \\
\hline Walbrzychskie & 1.3 & 6.3 & 7.6 & -5.0 & 2.6 \\
\hline Wloclawskie & 1.4 & 3.1 & 4.5 & -1.7 & 2.3 \\
\hline Wroclawskie & 4.7 & 5.1 & 9.9 & -0.4 & 8.6 \\
\hline Zamojskie & 2.0 & 4.2 & 6.2 & -2.2 & 2.9 \\
\hline Zielonogorskie & 3.3 & 8.1 & 11.4 & -4.8 & 4.4 \\
\hline
\end{tabular}


Table 5: Annual average job flows in Estonia according to regional units, 1994-1997

\begin{tabular}{lrrrrr}
\hline Group of Maakond & pos & Neg & gross & net & excess \\
& & & & & \\
\hline Põhja-Eesti & 4.6 & 6.0 & 10.6 & -1.4 & 7.5 \\
$\quad$ Tallinn & 11.3 & 9.4 & 20.7 & 1.9 & 15.6 \\
Kesk-Eesti & 3.8 & 5.4 & 9.2 & -1.6 & 7.2 \\
Kirde-Eesri & 4.4 & 8.9 & 13.4 & -4.5 & 6.0 \\
Lä̈̈ne-Eesti & 3.9 & 4.9 & 8.8 & -1.0 & 6.4 \\
Löuna-Eesti & 6.3 & 8.4 & 14.7 & -2.1 & 10.3 \\
\hline
\end{tabular}

Note: $(*)$ Tallinn belongs to Põhja-Eesti.

Table 6: Annual average job flows in Slovenia according to regional units, 1994-1997

\begin{tabular}{lccrrr}
\hline Statisticne Regije & pos & Neg & gross & net & excess \\
\hline Pomurska & 1.5 & 3.4 & 4.8 & -1.9 & 2.7 \\
Podravska & 6.0 & 6.1 & 12.1 & -0.1 & 9.3 \\
Koroška & 7.7 & 4.5 & 12.2 & 3.1 & 4.9 \\
Savinjska & 3.2 & 4.1 & 7.3 & -1.0 & 5.8 \\
Zasavska & 1.5 & 3.9 & 5.5 & -2.4 & 3.1 \\
Spodnjeposavska & 1.0 & 4.6 & 5.7 & -3.6 & 2.1 \\
Dolenjska & 5.0 & 5.2 & 10.1 & -0.2 & 7.3 \\
Osrednjeslovenska & 2.5 & 6.6 & 9.1 & -4.1 & 5.0 \\
$\quad$ Ljubljana* & 7.4 & 7.0 & 10.4 & 0.4 & 10.2 \\
Gorenjska & 4.5 & 4.4 & 8.8 & 0.1 & 7.5 \\
Notranjsko-kraška & 2.4 & 3.1 & 5.5 & -0.6 & 4.3 \\
Goriška & 2.5 & 3.7 & 6.2 & -1.2 & 3.6 \\
Obalno-kraška & 2.3 & 5.0 & 7.3 & -2.6 & 4.7 \\
\hline Note: (*): Ljubljna belong to Osradnjes
\end{tabular}

Note: $(*)$ : Ljubljana belongs to Osrednjeslovenska. 
Table 7: Annual average job flows in Bulgaria according to regional units, 1994-1997

\begin{tabular}{|c|c|c|c|c|c|}
\hline Oblast/Group of Obshtini & pos & $\mathrm{Neg}$ & gross & net & excess \\
\hline Sofia-grad & 2.2 & 5.4 & 7.6 & -3.2 & 4.4 \\
\hline \multicolumn{6}{|l|}{ Sofia-oblast } \\
\hline Sofia & 3.8 & 3.6 & 7.4 & 0.1 & 3.6 \\
\hline Pernik & 1.7 & 5.6 & 7.3 & -4.0 & 3.3 \\
\hline Kjustendil & 1.6 & 4.8 & 6.3 & -3.2 & 2.9 \\
\hline Blagoevgrad & 3.1 & 5.1 & 8.1 & -2.0 & 5.2 \\
\hline \multicolumn{6}{|l|}{ Montana-oblast } \\
\hline Vratza & 2.5 & 6.5 & 9.1 & -4.0 & 4.7 \\
\hline Montana & 2.2 & 6.1 & 8.4 & -3.9 & 4.2 \\
\hline Vidin & 1.1 & 7.3 & 8.4 & -6.1 & 2.2 \\
\hline \multicolumn{6}{|l|}{ Plovdiv-oblast } \\
\hline Plovdiv & 3.1 & 7.0 & 10.1 & -3.9 & 6.2 \\
\hline Pazardjik & 1.7 & 5.1 & 6.8 & -3.4 & 3.1 \\
\hline Smoljan & 2.2 & 4.9 & 7.1 & -2.7 & 2.1 \\
\hline \multicolumn{6}{|l|}{ Lovech-oblast } \\
\hline Veliko Tarnovo & 2.6 & 4.9 & 7.5 & -2.4 & 4.8 \\
\hline Gabrovo & 3.1 & 5.0 & 8.1 & -1.8 & 5.9 \\
\hline Lovech & 2.7 & 5.3 & 8.0 & -2.6 & 5.4 \\
\hline Pleven & 2.5 & 6.5 & 9.0 & -4.1 & 4.9 \\
\hline \multicolumn{6}{|l|}{ Haskovo-oblast } \\
\hline Stara Zagora & 2.8 & 5.1 & 7.9 & -2.3 & 2.2 \\
\hline Haskovo & 2.0 & 5.0 & 6.9 & -3.0 & 3.2 \\
\hline Kardjali & 2.9 & 8.1 & 11.0 & -5.1 & 5.9 \\
\hline \multicolumn{6}{|l|}{ Ruse-oblast } \\
\hline Ruse & 1.6 & 6.1 & 7.7 & -4.4 & 2.7 \\
\hline Razgrad & 2.6 & 3.9 & 6.6 & -1.3 & 4.2 \\
\hline Silistra & 1.7 & 6.5 & 8.2 & -4.8 & 3.3 \\
\hline Targovishte & 2.4 & 4.9 & 7.3 & -2.5 & 4.1 \\
\hline \multicolumn{6}{|l|}{ Burgas-oblast } \\
\hline Burgas & 2.2 & 5.8 & 8.0 & -3.7 & 4.1 \\
\hline Jambol & 2.2 & 7.9 & 10.1 & -5.8 & 4.1 \\
\hline Sliven & 2.7 & 6.0 & 8.7 & -3.3 & 3.8 \\
\hline \multicolumn{6}{|l|}{ Varna-oblast } \\
\hline Varna & 2.1 & 6.0 & 8.1 & -3.9 & 4.1 \\
\hline Dobrich & 3.8 & 7.1 & 10.8 & -3.3 & 6.2 \\
\hline Shumen & 2.5 & 5.0 & 7.5 & -2.5 & 4.7 \\
\hline
\end{tabular}


Table 8: Annual average job flows in Romania according to regional units, 1995-1997

\begin{tabular}{|c|c|c|c|c|c|}
\hline Judet & pos & $\mathrm{Neg}$ & gross & net & excess \\
\hline Municipiul Bucuresti & 4.5 & 9.3 & 13.8 & -4.8 & 9.0 \\
\hline Alba & 3.3 & 6.1 & 9.4 & -2.8 & 6.6 \\
\hline Arad & 4.8 & 7.9 & 12.7 & -3.1 & 9.6 \\
\hline Arges & 6.4 & 8.3 & 14.7 & -1.9 & 9.3 \\
\hline Bacãu & 3.2 & 7.0 & 10.3 & -3.8 & 6.5 \\
\hline Bihor & 8.0 & 9.9 & 17.9 & -1.8 & 12.4 \\
\hline Bistrita-Nãsãud & 2.2 & 9.7 & 12.0 & -7.5 & 4.5 \\
\hline Botosani & 9.2 & 6.7 & 16.0 & 2.5 & 13.3 \\
\hline Brasov & 2.3 & 7.8 & 10.0 & -5.5 & 4.6 \\
\hline Brãila & 3.9 & 13.4 & 17.4 & -9.5 & 7.8 \\
\hline Buzãu & 2.4 & 10.7 & 13.2 & -8.3 & 4.9 \\
\hline Caras-Severin & 2.0 & 7.3 & 9.3 & -5.3 & 4.0 \\
\hline Cãlãrasi & 4.1 & 13.3 & 17.4 & -9.2 & 6.7 \\
\hline Cluj & 2.6 & 7.1 & 9.7 & -4.5 & 5.2 \\
\hline Constanta & 5.2 & 12.0 & 17.2 & -6.8 & 10.4 \\
\hline Covasna & 2.9 & 4.8 & 7.7 & -1.9 & 5.7 \\
\hline Dâmbovita & 1.3 & 7.4 & 8.7 & -6.0 & 2.7 \\
\hline Dolj & 3.1 & 9.6 & 12.7 & -6.5 & 6.2 \\
\hline Galati & 2.0 & 5.1 & 7.1 & -3.0 & 4.1 \\
\hline Giurgiu & 3.6 & 12.3 & 15.9 & -8.8 & 7.1 \\
\hline Gorj & 2.4 & 8.1 & 10.5 & -5.7 & 4.8 \\
\hline Harghita & 4.7 & 7.7 & 12.4 & -3.0 & 9.2 \\
\hline Hunedoara & 1.4 & 5.5 & 7.0 & -4.1 & 2.8 \\
\hline Ialomita & 6.0 & 11.0 & 17.1 & -5.0 & 8.9 \\
\hline Iasi & 3.4 & 7.7 & 11.1 & -4.3 & 6.8 \\
\hline Maramures & 3.2 & 11.9 & 15.1 & -8.7 & 6.4 \\
\hline Mehedinti & 4.5 & 8.0 & 12.5 & -3.5 & 7.9 \\
\hline Mures & 2.8 & 8.9 & 11.7 & -6.2 & 5.5 \\
\hline Neamt & 2.7 & 10.7 & 13.5 & -8.0 & 5.4 \\
\hline Olt & 4.5 & 9.3 & 13.8 & -4.7 & 9.1 \\
\hline Prahova & 5.2 & 11.8 & 17.0 & -6.5 & 9.3 \\
\hline Satu Mare & 2.7 & 8.3 & 11.0 & -5.6 & 5.4 \\
\hline Sãlaj & 3.3 & 7.7 & 11.1 & -4.4 & 6.7 \\
\hline Sibiu & 2.7 & 8.2 & 11.0 & -5.5 & 5.5 \\
\hline Suceava & 3.0 & 10.9 & 13.9 & -7.9 & 6.0 \\
\hline Teleorman & 2.0 & 10.6 & 12.5 & -8.6 & 3.9 \\
\hline Timis & 12.9 & 12.6 & 25.4 & 0.3 & 11.0 \\
\hline Tulcea & 6.7 & 9.0 & 15.7 & -2.3 & 9.4 \\
\hline Vaslui & 3.4 & 7.2 & 10.6 & -3.7 & 6.2 \\
\hline Vâlcea & 3.8 & 8.5 & 12.3 & -4.6 & 6.5 \\
\hline Vrancea & 7.2 & 11.0 & 18.2 & -3.7 & 11.7 \\
\hline
\end{tabular}


Table 9: Correlation Coefficients

\begin{tabular}{l|l}
\hline Country & $\begin{array}{l}\text { Correlation between excess job reallocation and net employment growth } \\
\text { at the regional level }\end{array}$ \\
\hline Poland & 0.038 \\
Estonia & 0.549 \\
Slovenia & 0.517 \\
Bulgaria & 0.340 \\
Romania & 0.527 \\
\hline
\end{tabular}

Table 10: Annual average gross and net job flow rates according to ownership type 1994-1997

\begin{tabular}{lccccc}
\hline Country/Size & Pos & neg & gross & net & Excess \\
\hline Poland & & & & & \\
State firms & 1.6 & 4.2 & 5.8 & -2.5 & 3.3 \\
Foreign firms & 9.4 & 2.9 & 12.3 & 6.5 & 5.8 \\
Domestic private & 5.0 & 4.3 & 9.3 & 0.7 & 7.9 \\
firms & & & & & \\
Bulgaria & 1.9 & 5.6 & 7.5 & -3.7 & 3.7 \\
State firms & 3.6 & 4.8 & 8.3 & -1.2 & 5.6 \\
Foreign firms & 2.8 & 6.0 & 8.8 & -3.2 & 5.6 \\
Domestic private & & & & & \\
firms & & & & & \\
Romania* & 2.3 & 9.5 & 11.8 & -7.2 & 4.6 \\
State firms & 15.1 & 4.3 & 19.4 & 10.7 & 8.7 \\
Foreign firms & 5.3 & 8.7 & 14.0 & -3.4 & 10.6 \\
Domestic private & & & & & \\
firms & & & &
\end{tabular}

Note: $(*)$ Romanian figures refer to 1995-1997 averages.

Domestic private firms are a residual category. Ownership information is not available for Estonia and Slovenia. 
Table 11: Annual average gross and net job flow rates according to firm size, 1994-1997

\begin{tabular}{|c|c|c|c|c|c|}
\hline Country/Size & pos & neg & gross & net & excess \\
\hline \multicolumn{6}{|l|}{ Bulgaria } \\
\hline $0-249$ & 2.6 & 8.0 & 10.6 & -5.3 & 5.3 \\
\hline $250-499$ & 2.8 & 7.2 & 10.0 & -4.4 & 5.6 \\
\hline $500-999$ & 2.7 & 6.9 & 9.6 & -4.2 & 5.3 \\
\hline+1000 & 2.2 & 4.2 & 6.5 & -2.0 & 4.1 \\
\hline \multicolumn{6}{|l|}{ Romania* } \\
\hline $0-249$ & 7.5 & 15.4 & 22.9 & -7.9 & 15.0 \\
\hline $250-499$ & 5.2 & 13.1 & 18.3 & -7.9 & 10.4 \\
\hline $500-999$ & 3.7 & 11.8 & 15.6 & -8.1 & 7.5 \\
\hline+1000 & 3.2 & 6.2 & 9.4 & -3.1 & 6.4 \\
\hline \multicolumn{6}{|l|}{ Estonia } \\
\hline $0-249$ & 7.1 & 12.7 & 19.8 & -5.6 & 12.9 \\
\hline $250-499$ & 6.2 & 9.6 & 15.9 & -3.4 & 12.1 \\
\hline $500-999$ & 9.1 & 4.5 & 13.6 & 4.5 & 7.6 \\
\hline+1000 & 12.9 & 9.3 & 22.2 & 3.6 & 13.5 \\
\hline \multicolumn{6}{|l|}{ Poland } \\
\hline $0-249$ & 7.9 & 15.6 & 23.4 & -7.7 & 15.7 \\
\hline $250-499$ & 6.1 & 9.4 & 15.5 & -3.4 & 11.9 \\
\hline $500-999$ & 4.5 & 7.2 & 11.7 & -2.7 & 9.0 \\
\hline+1000 & 3.1 & 5.3 & 8.4 & -2.2 & 6.2 \\
\hline \multicolumn{6}{|l|}{ Slovenia } \\
\hline $0-249$ & 4.4 & 6.7 & 11.2 & -2.3 & 8.9 \\
\hline $250-499$ & 3.7 & 5.1 & 8.9 & -1.4 & 6.9 \\
\hline $500-999$ & 5.5 & 5.4 & 10.9 & 0.2 & 10.1 \\
\hline+1000 & 4.3 & 4.6 & 8.9 & -0.3 & 5.8 \\
\hline
\end{tabular}

Note: $(*)$ Romanian figures refer to 1995-1997 averages. 
Table 12 Fraction of excess job reallocation resulting from employment shifts between sectors (in \%)

\begin{tabular}{lrrrr}
\hline Country & 1994 & 1995 & 1996 & 1997 \\
& & & & \\
\hline Poland & 0.1 & 2.7 & 2.5 & 15.7 \\
Estonia & 18.3 & 28.5 & 35.0 & 28.9 \\
Slovenia & 14.2 & 27.9 & 57.6 & 10.5 \\
Bulgaria & & 23.7 & 12.3 & 5.0 \\
Romania & & 0.9 & 6.5 & 26.9 \\
\hline
\end{tabular}

Note: Sectors are classified according to the NACE Rev.1, 1-digit classification.

Table 13: Fraction of excess job reallocation resulting from employment shifts between regions (in \%)

\begin{tabular}{lrrrr}
\hline Country & 1994 & 1995 & 1996 & 1997 \\
& & & & \\
\hline Poland & 14.1 & 20.1 & 12.3 & 26.6 \\
Estonia & 3.0 & 16.1 & 13.9 & 26.7 \\
Slovenia & 17.2 & 17.8 & 29.3 & 0.6 \\
Bulgaria & & 30.3 & 2.6 & 1.1 \\
Romania & & 8.0 & 21.9 & 0.6 \\
\hline
\end{tabular}

Note: Regions are classified according to the Eurostat Nomenclature for statistical regions in Central European countries (level 3): 28 counties in Bulgaria, 41 in Romania, 5 in Estonia, 49 in Poland and 12 in Slovenia.

Table 14: Fraction of excess job reallocation resulting from employment shifts between employer sizes (in \%)

\begin{tabular}{lrrrr}
\hline Country & 1994 & 1995 & 1996 & 1997 \\
& & & & 2.2 \\
\hline Poland & 0.1 & 1.0 & 2.9 & 26.4 \\
Estonia & 20.5 & 35.3 & 29.7 & 0.0 \\
Slovenia & 9.3 & 9.8 & 6.4 & 1.1 \\
Bulgaria & & 4.1 & 0.0 & 0.0 \\
Romania & & 0.6 & 0.6 \\
\hline
\end{tabular}

Note: Employer size classes are 0-49, 50-99, 100-249, 250-499, 500-999 and +1000.

Table 15: Fraction of excess job reallocation resulting from employment shifts between enterprise types (in \%)

\begin{tabular}{lcrrr}
\hline Country & 1994 & 1995 & 1996 & 1997 \\
& & & & 12.7 \\
\hline Poland & 6.1 & 10.8 & 0.9 & 5.4 \\
Bulgaria & & 6.3 & 1.9 & 0.0 \\
Romania & & 6.1 & 2.3 \\
\hline
\end{tabular}

Note: Enterprise type categories are foreign-owned, state-owned and domestic enterprises. 
Table 16: Firm growth regression results (robust estimation), Poland

\begin{tabular}{lccccc}
\hline & $(1)$ & $(2)$ & $(3)$ & $(4)$ & $(5)$ \\
\hline Trade orientation & $-0.012^{\mathrm{a}}$ & $-0.011^{\mathrm{c}}$ & -0.006 & -0.011 & -0.010 \\
& $(0.002)$ & $(0.006)$ & $(0.006)$ & $(0.008)$ & $(0.009)$ \\
State & & $-0.021^{\mathrm{a}}$ & $-0.022^{\mathrm{a}}$ & $-0.019^{\mathrm{b}}$ & $-0.154^{\mathrm{a}}$ \\
& & $(0.007)$ & $(0.007)$ & $(0.010)$ & $(0.06)^{\mathrm{c}}$ \\
Foreign & & $0.044^{\mathrm{a}}$ & $0.032^{\mathrm{a}}$ & 0.014 & $0.091^{\mathrm{c}}$ \\
& & $(0.007)$ & $(0.008)$ & $(0.011)$ & $(0.056)$ \\
$n_{i, t-2}$ & & & & $-0.009^{\mathrm{a}}$ & $-0.017^{\mathrm{a}}$ \\
$n_{i, t-2^{*} \text { state }}$ & & & $(0.004)$ & $(0.005)$ \\
$n_{i, t-2^{*} \text { foreign }}$ & & & & $0.019^{\mathrm{b}}$ \\
Regional dummies & & & & & $(0.008)$ \\
Year dummies & & & & & -0.012 \\
$n$. of obs. & No & No & Yes & Yes & Yes \\
Yes & Yes & Yes & Yes & Yes \\
\hline
\end{tabular}

Note: (a): significant at 1\% level, (b): significant at 5\% level and (c): significant at $10 \%$ level; standard errors are reported in brackets. 
Table 17: Firm growth regression results (robust estimation), Estonia

\begin{tabular}{lccc}
\hline & $(1)$ & $(2)$ & $(3)$ \\
\hline Trade orientation & $-0.052^{\mathrm{a}}$ & $-0.051^{\mathrm{a}}$ & $-0.057^{\mathrm{b}}$ \\
& $(0.019)$ & $(0.019)$ & $(0.025)$ \\
$n_{i, t-2}$ & & & $-0.041^{\mathrm{a}}$ \\
& & & $(0.006)$ \\
Regional dummies & No & Yes & Yes \\
Year dummies & Yes & Yes & Yes \\
n. of obs. & 893 & 893 & 535 \\
\hline
\end{tabular}

Note: (a): significant at 1\% level, (b): significant at 5\% level and (c): significant at $10 \%$ level; standard errors are reported in brackets.

Table 18: Firm growth regression results (robust estimation), Slovenia

\begin{tabular}{lccc}
\hline & $(1)$ & $(2)$ & $(3)$ \\
\hline Trade orientation & $-0.008^{\mathrm{b}}$ & $-0.009^{\mathrm{b}}$ & $-0.010^{\mathrm{b}}$ \\
& $(0.004)$ & $(0.004)$ & $(0.002)$ \\
$n_{i, t-2}$ & & & $-0.014^{\mathrm{a}}$ \\
& & & $(0.002)$ \\
Regional dummies & No & Yes & Yes \\
Year dummies & Yes & Yes & Yes \\
$n$. of obs. & 2026 & 2026 & 1482 \\
\hline
\end{tabular}

Note: (a): significant at 1\% level, (b): significant at 5\% level and (c): significant at 10\% level; standard errors are reported in brackets. 
Table 19: Firm growth regression results (robust estimation), Bulgaria

\begin{tabular}{|c|c|c|c|c|c|}
\hline & (1) & (2) & (3) & (4) & (5) \\
\hline \multirow[t]{2}{*}{ Trade orientation } & $0.010^{\mathrm{a}}$ & $0.006^{\mathrm{a}}$ & $0.006^{\mathrm{b}}$ & $0.006^{\mathrm{b}}$ & $0.007^{\mathrm{b}}$ \\
\hline & $(0.002)$ & $(0.002)$ & $(0.002)$ & $(0.003)$ & $(0.003)$ \\
\hline \multirow[t]{2}{*}{ State } & & $-0.005^{b}$ & $-0.005^{b}$ & -0.001 & $-0.045^{b}$ \\
\hline & & $(0.002)$ & $(0.002)$ & $(0.003)$ & $(0.017)$ \\
\hline \multirow[t]{2}{*}{ Foreign } & & $0.015^{b}$ & $0.013^{b}$ & $0.013^{\mathrm{c}}$ & 0.028 \\
\hline & & $(0.006)$ & $(0.006)$ & $(0.007)$ & $(0.043)$ \\
\hline$n_{i, t-2}$ & & & & $\begin{array}{c}-0.006^{\mathrm{a}} \\
(0.001)\end{array}$ & $\begin{array}{l}-0.010^{\mathrm{a}} \\
(0.002)\end{array}$ \\
\hline$n_{i, t-2} *$ state & & & & & $\begin{array}{l}0.008^{b} \\
(0.003)\end{array}$ \\
\hline$n_{i, t-2}{ }^{*}$ foreign & & & & & $\begin{array}{c}-0.002 \\
(0.007)\end{array}$ \\
\hline Regional dummies & No & No & Yes & Yes & Yes \\
\hline Year dummies & Yes & Yes & Yes & Yes & Yes \\
\hline n. of obs. & 7865 & 6891 & 6891 & 4679 & 4679 \\
\hline
\end{tabular}

Note: (a): significant at $1 \%$ level, (b): significant at 5\% level and (c): significant at $10 \%$ level; standard errors are reported in brackets.

Table 20: Firm growth regression results (robust estimation), Romania

\begin{tabular}{lccccc}
\hline & $(1)$ & $(2)$ & $(3)$ & $(4)$ & $(5)$ \\
\hline Trade orientation & $0.007^{\mathrm{a}}$ & $0.011^{\mathrm{a}}$ & $0.011^{\mathrm{a}}$ & $0.012^{\mathrm{a}}$ & $0.011^{\mathrm{a}}$ \\
& $(0.003)$ & $(0.003)$ & $(0.003)$ & $(0.003)$ & $(0.003)$ \\
State & & $-0.031^{\mathrm{a}}$ & $-0.032^{\mathrm{a}}$ & $-0.021^{\mathrm{a}}$ & $-0.134^{\mathrm{a}}$ \\
& & $(0.003)$ & $(0.003)$ & $(0.003)$ & $(0.019)$ \\
Foreign & & $0.106^{\mathrm{a}}$ & $0.109^{\mathrm{a}}$ & $0.108^{\mathrm{a}}$ & $0.256^{\mathrm{a}}$ \\
& & $(0.008)$ & $(0.008)$ & $(0.009)$ & $(0.038)$ \\
$n_{i, t-2}$ & & & $-0.006^{\mathrm{a}}$ & $-0.016^{\mathrm{a}}$ \\
& & & & $(0.001)$ & $(0.002)$ \\
$n_{i, t-2}{ }^{*}$ state & & & & $0.019^{\mathrm{a}}$ \\
& & & & & $(0.003)$ \\
$n_{i, t-2}{ }^{*}$ foreign & & & & & $-0.027^{\mathrm{a}}$ \\
& & & & & $(0.007)$ \\
Regional dummies & No & No & Yes & Yes & Yes \\
Year dummies & Yes & Yes & Yes & Yes & Yes \\
$n$. of obs. & 11023 & 8146 & 8146 & 5203 & 5203 \\
\hline Nob & & & & & \\
\hline
\end{tabular}

Note: (a): significant at 1\% level, (b): significant at 5\% level and (c): significant at $10 \%$ level; standard errors are reported in brackets. 


\section{IZA Discussion Papers}

No Author(s)

151 M. Ward

152 J. J. Dolado

F. Felgueroso

J. F. Jimeno

153 A. S. Kalwij

M. Gregory

154 M. Gerfin

M. Lechner

155 J. Hansen

156 C. Dustmann

F. Fabbri

157 P. Apps

R. Rees

158 A. Björklund

T. Eriksson

M. Jäntti

O. Raaum

E. Österbacka

159 P.- J. Jost

M. Kräkel

160 M. Lofstrom

161

V. Gimpelson

D. Treisman

G. Monusova

162 C. Dustmann

M. E. Rochina-

Barrachina

163 R. A. Hart

Y. Ma

164 M. A. Shields

S. Wheatley Price

165
Titel

Area

Date

Gender, Salary and Promotion in the Academic Profession

The Role of the Minimum Wage in the Welfare 3 State: An Appraisal

5

$5 / 00$

$5 / 00$

Overtime Hours in Great Britain over the Period 3

1975-1999: A Panel Data Analysis

Microeconometric Evaluation of the Active Labour 6

Market Policy in Switzerland

The Duration of Immigrants' Unemployment Spells: $\quad 1 / 3$

Evidence from Sweden

Language Proficiency and Labour Market Per- 1

formance of Immigrants in the UK

Household Production, Full Consumption and

7

the Costs of Children

Brother Correlations in Earnings in Denmark, 5

Finland, Norway and Sweden Compared to the United States

Preemptive Behavior in Sequential Tournaments

5

$5 / 00$

A Comparison of the Human Capital and Signaling Models: The Case of the Self-Employed and the Increase in the Schooling Premium in the 1980's

Public Employment and Redistributive Politics: 4 Evidence from Russia's Regions

Selection Correction in Panel Data Models: An 6 Application to Labour Supply and Wages

$6 / 00$

Why do Firms Pay an Overtime Premium?

5

$6 / 00$

Racial Harassment, Job Satisfaction and Intentions

5

$6 / 00$

to Quit: Evidence from the British Nursing Profession

Immigration in a High Unemployment Economy: 1 The Recent Danish Experience 
B. Nolan

Earnings Inequality, Returns to Education and 5

Immigration Policy in Integrated National

$7 / 00$

171 C. Dustmann Economies

Wages and the Demand for Health - A Life Cycle

Analysis

172 D. Card

Reforming the Financial Incentives of the Welfare System 

J. M. Abowd
F. Kramarz
D. N. Margolis
T. Philippon

204

G. S. Epstein

A. L. Booth

M. Francesconi

J. Frank

C. M. Schmidt

R. Baltussen

R. Sauerborn

J. Hartog

R. Winkelmann

209

M. Barbie

M. Hagedorn

A. Kaul

210 T. J. Dohmen

211
A. van Soest
M. Das
X. Gong

212 X. Gong

A. van Soest

P. Zhang

213 X. Gong

A. van Soest

E. Villagomez

$214 \quad$ X. Gong

A. van Soest

215 J. Ermisch

M. Francesconi

216 F. Büchel
The Tail of Two Countries: Minimum Wages and 5

Employment in France and the United States
$9 / 00$

Labor Market Interactions Between Legal and

1

$10 / 00$

Ilegal Immigrants

Temporary Jobs: Stepping Stones or Dead Ends? 1

$10 / 00$

The Evaluation of Community-Based Interventions: Group-Randomization, Limits and

6

$10 / 00$ Alternatives

Arbeitsmarktpolitische Maßnahmen und ihre

Dutch Migrants in New Zealand:

$10 / 00$

Did they Fare Well?

Dynamic Effciency and Pareto Optimality in a

3

$10 / 00$

Stochastic OLG Model with Production and Social

Security

Housing, Mobility and Unemployment

$11 / 00$

A Structural Labour Supply Model with

5

$11 / 00$

Nonparametric Preferences

Sexual Bias and Household Consumption: A

5

Semiparametric Analysis of Engel Curves in Rural China

Mobility in the Urban Labor Market: A Panel Data 1 Analysis for Mexico

Family Structure and Female Labour Supply in

5

$11 / 00$ Mexico City

The Effect of Parents' Employment on Children's

5

$11 / 00$ 

when? and Earnings: An Empirical Study for Portugal 

1969-95 